\title{
WATER QUALITY IN PREMISE PLUMBING SYSTEM - A REVIEW
}

\author{
Shree D. Kamble ${ }^{1}$, Guru R. Munavalli ${ }^{2}$ \\ ${ }^{1}$ M.Tech Student, Walchand College of Engineering, Sangli, 416415, India \\ ${ }^{2}$ Associate Professor, Walchand College of Engineering, Sangli, 416415, India
}

\begin{abstract}
Water quality is now a growing concern throughout the world since water happens to be lifeline for human beings. Most of the research till date has focused on drinking water quality in distribution systems. But it has been reported that chemical and bacterial changes takes place as the water moves from distribution system to the consumers tap. Biofilms have been reported to occur in plumbing system. However not much data is available about the behavior of premise plumbing system with respect to Indian context as far as water quality is considered. The purpose of this study is to understand water quality in premise plumbing system. This article attempts to review various studies undertaken by researchers in order to assess water quality in plumbing system. The methodology of these studies and outcomes are learnt, with reference to Indian context. The gaps in studies and possible directions for future studies are also discussed in this article.
\end{abstract}

Keywords: Biofilm, Heterotrophic Plate Count (HPC), Premise plumbing system, Water quality ****

\section{INTRODUCTION}

Water has always been a vital and life-sustaining resource for the survival of human beings. Though there are plentiful sources of water, the addition of key word potability to water reduces to a great extent the amount of acceptable useful water on earth [18]. Globally, around $89 \%$ of people have access to potable water. About 1.8 billion people still use an unsafe drinking water which can result in diarrhoea [20]. Diarrhoeal disease alone claims the lives of 5000 children every day. These disease-causing microorganisms are predominantly of faecal origins which are referred as enteric pathogens [2], [8]. Moreover, nowadays, due to increased urbanization, frequent droughts and changing climate patterns, water quality has become a serious issue.

Safe drinking water is necessary for good public health. However drinking water also possesses potential to carry disease causing micro-organisms which is well recognized in both developed and developing countries. Besides microorganisms, chemical contaminants are also present in water which might pose a threat to human health. After distribution system, it is the plumbing system that distributes water within the building. Most research work till date has focused on water quality in distribution system and not including consumers plumbing system. But it is seen that water quality changes as the water moves from distribution system to consumers tap. Drinking water usually meets the chemical and microbiological quality standards, but chemical changes and microbiological establishment that reduce the water quality often occur within buildings and human-made structures [12], [14], [21]. Bacterias have been reported to occur in plumbing system but little is known about their behavior in premise plumbing system as far as Indian context is considered. Thus, water quality in plumbing system itself is more important. Since drinking water should meet the necessary quality requirements at the point of consumption [7], there is need to understand water quality in premise plumbing system.

This article attempts to provide a review of the current literature relating to water quality found in premise plumbing system. A review of various studies undertaken by researchers to assess water quality in plumbing system has been addressed in this paper. The paper deals with various methodologies adopted by researchers along with the important outcomes of the study. As only a handful of studies specifically relating to premise plumbing system have been published, an effort is made to identify gaps in studies and future work that can be undertaken in order to assess water quality in premise plumbing system.

\section{REVIEW ON PREVIOUS WORK DONE}

\subsection{Effect of Plumbing Materials}

Few researchers tried to investigate the chemical and microbial changes due to plumbing materials. The study undertaken by various researchers included materials like Cross-linked Polyethylene (PEX) [10], Copper [10], [15], [19], plastic [15], [19], Polyethylene (PE) [15], Polyvinyl chloride (PVC) [5].The results showed that biofilm formation was higher in PE pipes than in copper pipes during short period of study but for longer period, biofilm formation was same in both pipes [15]. Another study investigated that PVC was highest promoter of biofilm formation [5]. Also, the HPC's were three times higher in hot water system of copper pipes than PEX pipes [10]. More amount of leaching was seen in copper pipes than PEX pipes [10] with high AOC concentrations in PEX pipes [10]. Higher concentrations of copper and manganese were observed in copper plumbing and iron and zinc in plastic pipes [19] indicating leaching of metals in plumbing system is a material property. 


\subsection{Effect of Operational Conditions}

Few investigators examined the effect of operational conditions viz. stagnation of water and flushing on water quality. Few of them assessed bacterial quality [13], [10] while few of them studied leaching of metals in water. [10]. Stagnation of water significantly affects the water quality. It was seen that HPC were 4-50 folds higher in stagnated than in flushed water samples [13]. Moreover, intense values of HPC were observed on $3^{\text {rd }}$ floor when water was stagnant for about 1- 4 weeks [10]. Flushing of tap reduces HPC count considerably [13]. The cell concentration increased till $12 \mathrm{~h}$ of stagnation indicating bacterial growth is substrate limited [13]. Leaching of metals also take place in stagnated water from hot and cold water system during commissioning process [10].

\subsection{Impact of Tank Material and Cleaning Frequency}

A few researchers attempted to assess the chemical [1], [11] and bacteriological [1], [18] water quality in household storage tanks. Few of them worked on assessing impact of tank material and cleaning frequency on water quality [6]. It was found that HPC were always detected in storage tanks.[1], [11], [18]. The HPC values were higher in steel tanks [1] than black plastic, fiber cement and grey plastic tanks [6]. The maximum number of fecal bacterias (236 $\mathrm{CFU} / \mathrm{ml}$ ) were detected in black plastic tank at low chlorine concentration [6] while no bacterias were detected at high chlorine concentrations. [11], [1]. Higher levels of $\mathrm{Zn}, \mathrm{Pb}$, and $\mathrm{Fe}$ were observed in stored water during summer season [11]. THM's were also detected below permissible limits in storage tanks [1]. The frequency of cleaning storage tank also has impact on microbial quality of water. Storage tanks cleaned 3 or more times per year have less E. coli than tanks cleaned less frequently [6]. However, cleaning of roof storage tank doesn't affect chlorine concentrations in tanks [1].

\subsection{Effect of Cold vs. Hot Water Systems}

Few researchers tried to assess water quality in hot and cold water systems. Some of them worked on assessing microbiological quality in hot water systems [3], [4], [10]. Few of them assessed leaching of metals in hot and cold water systems. [10]. HPC's in hot water pipes were found to be higher than cold water pipes [3] except one study which contradicted this fact [10]. A majority of bacteria (72\%) were found in attached phase in the form of biofilms [3]. Besides bacteria, leaching of metals such as nickel, copper, zinc was observed more in hot water system than cold water system. [10]. Similar trend was observed for AOC concentrations [10]. However higher concentrations of DO, FRC were detected in cold water system [10]. Also the variations in temperature were seen between water meter and kitchen taps [16]. The trace element concentration was observed to increase risk of colonization in hot water samples [4].

\section{DISCUSSIONS}

From above paragraphs, it is seen that pipe material influences microbial community and formation rate of biofilms differs for different pipe materials. Biofilms develop in plumbing system because plumbing pipes either provides nutrients and / or conditions for bacterial growth. Since different plastic materials are made up of different additive chemicals like stabilizers, plasticizers, lubricants, coloring agents etc., the organic compounds from pipes can leach at early and later stages. The phosphorous or carbon leaching from pipes act as a nutrient for microbes which was noticed in the referred studies [10], [15]. The amount of phosphorous or carbon present in material varies material to material indicating significance of material property. Besides plumbing material factors such as temperature, disinfectants, flow conditions etc. also affects bacterial growth [7]. Hence the bacterial growth and leaching of metals varies in different plumbing pipes.

From operational conditions, it was found that microbial growth is substrate limited and there are variations in HPC at different floors [13]. Higher HPC was observed in stagnant water which could be explained by the fact that when water is stagnant, the concentration of bacteria in the bulk water per unit length of pipe might be much higher than when the flow is higher, provided that the rate at which bacteria enters the bulk water from biofilm is constant. The flushing of tap would receive only a part of bacteria from biofilm. Hence there might be high bacterial variation in stagnant and flushed water samples. Besides plumbing pipes, HPC were always detected in storage tanks. Usually, storage tanks are located on top of the building and are exposed to large amount of solar radiation for the most part of the day. As water stays for a long time in these tanks, an increase in temperature of water enhances bacterial growth and leaching of metals. Hence higher HPC count was observed during summer season due to depletion of chlorine [1]. However residence time seems to have more influence than ambient temperature [16].

Higher HPC was observed in hot water pipes than cold water pipes as bacterial growth is temperature dependent. An increased temperature causes leaching of metals from pipes to water [11] as chemical reactions accelerate with temperature [10]. The lower DO concentration in hot water system may be due to dissolution of gases owing to increased temperature [10]. Operational conditions within building could be the reason for increased HPC count in cold water system as found in one of the study [10].

From above studies, it was found that plumbing material did not have major effect on microbial biomass in early stages [10], [15] but it was also found that plumbing age and material has significant effect on leaching of heavy metals in early and later stages [19]. The results obtained from pilot network [15] may not be applicable for real case study. Moreover, the results obtained for one kind of plastic material cannot be generalized to all plastic materials. Hence a clear understanding regarding influence of commonly used piping materials on water quality is necessary. Some studies 
included different households that were chosen randomly. As each building is different from other, water quality could vary among the building. Thus a criteria need to be thought of while choosing a building. Many researchers have examined water quality either in hot and cold water system or in storage tanks. However no study attempted to understand water quality variation from location to location. Several studies focused on measuring HPC whose health effects on human health are not yet understood. Studies can be undertaken in detecting pathogenic microorganisms whose health effects are well documented in developed and developing countries.

Literature review reveals that various contributions made by researchers have identified issues related to the domestic plumbing system. Since chemical and bacteriological quality varies at each location, there is scope in understanding and evaluating water quality within the premise plumbing system. Microbiological studies may be undertaken along with chemical analysis, in order to the test water for potability [11]. Also, past modeling work at the building level is limited. Hence it is essential to develop water quality models at building level that can assess vulnerability of building for contaminant levels [9]. Although researchers suggested short flushing of tap as a mitigation measure [13], [17] there is need to decide a strategy for controlling bacterial growth at household level. Since worldwide there are different climatic conditions, water qualities, and different materials used in the premise plumbing system, the scenario may be quite different in a developing country like India.

\section{CONCLUSION}

It is seen that water quality undergoes chemical and microbial changes in plumbing system. All the above literatures reported by researchers are from developed countries and none of such studies have been dealt in India. Moreover biofilms are bound to occur in plumbing system indicating bacterial growth in building is a general problem. There are several factors affecting plumbing system that are partly understood. Hence there is need to understand relationship between drinking water and pipe material giving due consideration to environmental and material factors. This would create awareness among people regarding the water quality they receive and water quality they drink.

\section{ACKNOWLEDGEMENTS}

This work was supported in part by a grant from Technical Education Quality Improvement Program (TEQIP-II).

\section{REFERENCES}

[1]. Al-omari A, Fayyad M., Jamrah A, Drinking water quality in roof storage tanks in the city of Amman, Jordan. Water International, 2008; 33(2): 189-201.

[2]. Ashbolt, N.J., W.O.K. Grabow and M. Snozzi. Indicators of microbial water quality. Water Quality: Guidelines, Standards and Health. 2001; 290-315
[3]. Bagh LK, Albrechtsen HJ, Arvin E, Ovesen K, Distribution of bacteria in a domestic hot water system in a Danish apartment building. Water Research, 2004; 38(1): 225-235.

[4]. Bargellini A, Marchesi I, Righi E, Ferrari A, Cencetti S, Borella P, Rovesti S. Parameters predictive of Legionella contamination in hot water systems: Association with trace elements and heterotrophic plate counts. Water Research, 2011; 45: 2315-2321.

[5]. Cloete TE, Westaard D, Van Vuuren SJ. Dynamic Response of Biofilm to pipe surface and Fluid velocity. Water Science and Technology, 2003; 47:5:57.

[6]. Cynthia AS. Impact of Tank Material on Water Quality in Household Water Storage Systems in Cochabamba, Bolivia, Master thesis, University of South Florida; 2010.

[7]. Eboigbodin KE, Seth A, Biggs CA. A review of biofilms in domestic plumbing. Journal of AWWA, 2008; 100(10): 131-138.

[8]. Edberg SC, Rice EW, Karlin RJ, Allen MJ. Escherichia coli: the best biological drinking water indicator for public health protection. Symp Ser Soc Appl Microbiol, 2000; 29: 106-116.

[9]. Grayman WM, Buchberger S, Samuels W. Hydraulic Models of Buildings for use in contamination studies. Proceedings of the 10th Annual Water Distribution Systems Analysis Conference WDSA, Kruger National Park, South Africa, August 17-20, 2008.

[10]. Inkinen J, Kaunisto T, Pursiainen A, Miettinen I, Kusnetsov J, Riihinen k, Keindnen-Toivola M. Drinking water quality and formation of biofilms in an office building during its first year of operation, a full scale study. Water Research, 2014; 49: 83-91.

[11]. Jawad IM, Al-Ghazili M.R, H. Khorshid MS. Effect of domestic storage tank on the quality of drinking waters. Environmental Monitoring and Assessment. 1988; 11: 7987.

[12]. Kilb B, Lange B, Schaule G, Flemming HC, Wingender J. Contamination of drinking water by coliforms from biofilms grown on rubber-coated valves. International Journal of Hygiene and Environmental Health, 2003; 206(6): 563-573.

[13]. Lautenschlager K, Boon N, Wang Y, Egli T, Hammes F. Overnight stagnation of drinking water in household taps induces microbial growth and changes in community composition. Water Research, 2010; 44(17): 4868-4877.

[14]. Lehtola MJ, Nissinen TK, Miettinen IT, Martikainen PJ, Vartiainen T. Removal of soft deposits from the distribution system improves the drinking water quality. Water Research, 2004; 38 (3): 601-610.

[15]. Lehtola MJ, Miettinen IT, Keinanen MM, Kekki TM, Laine O, Hirvonen A, Vartiainen T, Martikainen PJ.. Microbiology, chemistry and biofilm development in a pilot drinking water distribution system with copper and plastic pipes. Water Research, 2004; 38(17): 3769-3779.

[16]. Moerman A, Blokker M, Vreeburg J, van der Hoek JP. Drinking water temperature modeling in Domestic systems. 16th Conference on Water Distribution System Analysis, WDSA 2014, Procedia Engineering 89, 2014; 143-150. 
[17]. Pepper IL, Rusin P, Quintanar DR, Haney C, Josephson KL, Gerba CP. Tracing the concentration of heterotrophic plate count bacteria from the source to the consumer's tap. International Journal of Food Microbiology, 2004; 92: 289-295.

[18]. Sule IO, Agbabaika TO, Akomolafe AV, Bacteriological quality of water stored exteriorly in storage tanks. Research Journal of Environmental Sciences, 2011

[19]. Viraraghavan T, Subramanian KS, Tanjore S. Impact of household plumbing materials on trace metal levels in drinking water in Regina, Canada. Environmental and Pipeline Engineering, 2000; 561-570.

[20]. "Water Fact sheet N³91". July 2014. Retrieved 24 May 2015.

[21]. Wingender J, Flemming HC, Contamination potential of drinking water distribution network biofilms. Water Science and Technology, 2004; 49 (11-12), 277-286. 